\title{
Prevalence of Subclinical Hypothyroidism in Patients with Metabolic Syndrome
}

\author{
MeHMEt UZUNLULU, ELIF YORULMAZ AND AYTEKIN OGUZ \\ Department of Internal Medicine, Goztepe Training and Research Hospital, Istanbul, Turkey
}

\begin{abstract}
Subclinical hypothyroidism (SCH) is a prevalent condition among adult population, however it is frequently overlooked. Thyroid functions affect metabolic syndrome (MetS) parameters including HDL cholesterol, triglycerides, blood pressure and plasma glucose. On the other hand, the relation between MetS and thyroid dysfunction is not clearly identified yet. The aim of the present study was to investigate the prevalence of SCH among MetS patients and to identify its relation with MetS parameters. Two hundred and twenty MetS patients (MetS group; 167 female, 53 male, mean age: $48.5 \pm 11.3$ ) and 190 patients without MetS (Control group; 142 female, 48 male, mean age: $46.3 \pm 11.9$ ) attending consecutively to Internal Medicine outpatient clinics were included in this study. Groups were compared in terms of SCH prevalence. SCH was defined as a condition with high thyrotrophin and normal free thyroxine levels. SCH was found in $36(16.4 \%)$ cases in the MetS group and in $11(5.8 \%)$ cases in the control group $(p=0.001)$. Only female gender was associated with the presence of SCH. About one sixth of MetS patients had SCH. This finding indicates a need for investigating the presence of SCH during the management of MetS patients.
\end{abstract}

Key words: Subclinical hypothyroidism, Metabolic syndrome

(Endocrine Journal 54: 71-76, 2007)

METABOLIC syndrome (MetS) is a cluster of risk factors and characterized by hypertension, atherogenic dyslipidemia, hyperglycemia, prothrombotic and proinflammatory conditions [1]. MetS is associated with an increased risk of atherosclerotic cardiovascular disease and type 2 diabetes [2]. Obesity, insulin resistance, physical inactivity, advanced age and hormonal imbalance have been suggested as the underlying risk factors for the development of the syndrome [3]. Epidemiological studies showed a high prevalence for MetS [4]. Subclinical hypothyroidism ( $\mathrm{SCH})$ is defined as an asymptomatic condition with high serum thyroid-stimulating hormone (TSH) levels and normal free thyroid hormone levels [5]. SCH has also been suggested as a risk factor for atherosclerotic cardiovascular disease, and metabolic disorders such as hyperlipidemia, hypertension, low grade inflammation and

Received: July 7, 2006

Accepted: October 16, 2006

Correspondence to: Dr. Mehmet UZUNLULU, Altaycesme Mahallesi, Sarigul Sokak, Kuralkan Sitesi, No: 4, B2 Blok, Daire: 20, 34843, Maltepe, Istanbul/Turkey hypercoagulability may accompany this process [6-8]. In the present study, we hypothesized that $\mathrm{SCH}$ may have an impact on the prevalence of MetS. With this aim, the prevalence of $\mathrm{SCH}$ was investigated in patients with and without MetS and the relation between $\mathrm{SCH}$ and MetS parameters was evaluated.

\section{Materials and Methods}

Two hundred and twenty patients with MetS and 190 controls were included in this study among consecutive patients attending the outpatient clinics of Goztepe Training and Research Hospital, Department of Internal Medicine. MetS patients required to fulfill NCEPATP III MetS diagnostic criteria and patients without MetS were allocated into the control group. Study protocol was approved by local ethics committee (approval date and number: 02-02-2005/20) and all patients gave written informed consent prior to study entry. The study was conducted in accordance with Declaration of Helsinki.

Patients with known diabetes or other endocrine dis- 
orders, patients receiving any medication that may alter thyroid functions or lipid levels, pregnant women, and patients with an abdominal mass or ascites, or severe liver, heart or renal failure were excluded.

MetS and control groups were compared in terms of $\mathrm{SCH}$ prevalence. In addition, bivariate and multivariate analyses were done to identify any relation between $\mathrm{SCH}$ and MetS parameters.

A diagnosis of MetS was made if at least three of the diagnostic criteria proposed by the American National Cholesterol Education Program Adult III Treatment Panel (NCEP-ATP III) were met [blood pressure $\geq 130$ / $85 \mathrm{mmHg}$ (or use of antihypertensive medication); fasting plasma glucose $\geq 110 \mathrm{mg} / \mathrm{dl}$ (or use of antidiabetic medication); fasting triglycerides $\geq 150 \mathrm{mg} / \mathrm{dl}$; HDL cholesterol $<40 \mathrm{mg} / \mathrm{dl}$ (men) or $<50 \mathrm{mg} / \mathrm{dl}$ (women); and waist circumference $>102 \mathrm{~cm}$ (men) or $>88 \mathrm{~cm}$ (women)] [9].

A high serum TSH level and a normal free thyroxine $\left(\mathrm{FT}_{4}\right)$ level were required for the diagnosis of $\mathrm{SCH}$ [5].

At baseline, demographic data was collected and a detailed physical examination was done. Sitting blood pressure was measured in both arms after at least 10 minutes of rest with an appropriate mercury sphygmomanometer using the Phase I and Phase IV Korotkoff sounds. A second measurement was made after at least 3 minutes in the arm with the highest measurement. The mean of two measurements was used for systolic and diastolic blood pressures. The waist circumference was measured at the plane between anterior superior iliac spines and lower costal margins at the narrowest part of the waistline while the patient was standing and during slight expiration. Body Mass Index (BMI) was calculated by using Quetlet index (weight $/$ height $^{2}-\mathrm{kg} / \mathrm{m}^{2}$ ) [10].

Blood samples obtained following 12 hours of fasting were immediately centrifuged $(2500 \mathrm{rpm})$ and the sera were separated. Glucose, total cholesterol, HDL cholesterol and triglyceride levels were determined by enzymatic methods. LDL cholesterol was determined by using Friedwald formula [11]. Serum TSH and $\mathrm{FT}_{4}$ measurements were made with Roche Elecsys Modular Analytics E170 (Elecsys module) device by using electrochemiluminescence immunoassay "ECLIA" method. The analytical sensitivity for TSH is $0.005 \mu \mathrm{IU} / \mathrm{ml}$ and for $\mathrm{FT}_{4}$ is $0.023 \mathrm{ng} / \mathrm{dL}$. The normal range for TSH is $0.27-4.2 \mu \mathrm{IU} / \mathrm{ml}$ and for $\mathrm{FT}_{4}$ is $0.93-1.7 \mathrm{ng} / \mathrm{dl}$.

Statistical analyses were made by using SPSS for Windows 10.0 software package. Inter-group compar- isons of quantitative variables were made by using student $\mathrm{t}$ test for parameters with normal distribution and Mann Whitney U test for parameters without normal distribution. Chi-square test and Fischer's Exact Chi Square test were used for the comparison of qualitative data. A p level $<0.05$ considered significant and $95 \%$ confidence intervals were calculated.

\section{Results}

A total of 410 patients were included in this study. MetS group consisted of 220 patients (167 female, 53 male, mean age $48.5 \pm 11.3)$ and control group included 190 patients (142 female, 48 male, mean age $46.3 \pm 11.9)$. Clinical characteristics of the groups are depicted in Table 1.

Groups were similar in terms of age, sex distribution, smoking and alcohol habits $(p>0.05)$. None of the groups had diabetic patient. Number of patients with hypertension was $190(86.4 \%)$ in the MetS group and $29(15.3 \%)$ in the control group. Mean values for systolic and diastolic pressure, BMI, waist circumference, fasting plasma glucose, triglycerides, total cholesterol, LDL cholesterol, and mean number of MetS criteria were higher in the MetS group compared to controls $(p<0.05)$. HDL cholesterol levels were lower in the MetS group compared to controls $(\mathrm{p}<0.05)$.

Overall, the prevalence of MetS and SCH was $53.6 \%$ (in females $40.7 \%$, in males $12.9 \%$ ) and $11.5 \%$ (in females $10 \%$, in males $1.5 \%$ ), respectively. $\mathrm{SCH}$ was found in $36(16.4 \%)$ cases in the MetS group and in 11 $(5.8 \%)$ cases in the control group $(p=0.001)$. Prevalence of SCH was higher in females with MetS compared to female controls $(p=0.0001)$, while it was similar in both group of male patients ( $\mathrm{p}>0.05)$ (Fig. 1). In both groups, all cases with SCH had a TSH level above the upper limit of normal and $\mathrm{FT}_{4}$ level within the normal range.

Bivariate analysis demonstrated that female gender was associated with $\mathrm{SCH}$. Multivariate analysis showed that female gender was associated with $\mathrm{SCH}$ [OR: 4.104 (1.205-13.982), $\mathrm{p}<0.05$ ] (Table 2, 3).

\section{Discussion}

The present study found SCH in about one sixth of MetS patients. MetS is a very frequent condition in the 
Table 1. Patient characteristics

\begin{tabular}{|c|c|c|c|c|}
\hline & & MetS group $(n=220)$ & Control Group $(n=190)$ & $\mathrm{p}$ \\
\hline Age (year) & & $48.5 \pm 11.3$ & $46.3 \pm 11.9$ & 0.07 \\
\hline \multirow[t]{2}{*}{ Gender, (n, \%) } & Female & $167(75.9)$ & $142(74.7)$ & 0.784 \\
\hline & Male & $53(24.1)$ & $48(25.3)$ & \\
\hline \multicolumn{2}{|l|}{ Smoking (n, \%) } & $30(13.6)$ & $21(11.1)$ & 0.429 \\
\hline \multicolumn{2}{|l|}{ Alcohol (n, \%) } & $16(7.2)$ & $12(6.3)$ & 0.702 \\
\hline \multicolumn{2}{|c|}{ Body mass index $\left(\mathrm{kg} / \mathrm{m}^{2}\right)$} & $32.4 \pm 4.7$ & $26.4 \pm 5$ & 0.0001 \\
\hline \multicolumn{2}{|c|}{ Systolic blood pressure (mmHg) } & $145.6 \pm 21.6$ & $116.3 \pm 18.4$ & 0.0001 \\
\hline \multicolumn{2}{|c|}{ Diastolic blood pressure $(\mathrm{mmHg})$} & $91.7 \pm 9.8$ & $75.7 \pm 10.9$ & 0.0001 \\
\hline \multicolumn{2}{|c|}{ Waist circumference $(\mathrm{cm})$} & $98.9 \pm 8.6$ & $87.1 \pm 10.7$ & 0.0001 \\
\hline \multicolumn{2}{|c|}{ Total cholesterol (mg/dl) } & $213.7 \pm 47.2$ & $187.5 \pm 40.1$ & 0.0001 \\
\hline \multicolumn{2}{|c|}{ LDL cholesterol (mg/dl) } & $126.2 \pm 44.5$ & $111.1 \pm 34.4$ & 0.001 \\
\hline \multicolumn{2}{|c|}{ HDL cholesterol (mg/dl) } & $44.9 \pm 10.7$ & $53 \pm 15.9$ & 0.0001 \\
\hline \multicolumn{2}{|c|}{ Triglycerides (mg/dl) } & $199.4 \pm 100.7$ & $111.7 \pm 62.6$ & 0.0001 \\
\hline \multicolumn{2}{|c|}{ Fasting blood glucose (mg/dl) } & $107.3 \pm 11.7$ & $95.3 \pm 10.6$ & 0.0001 \\
\hline \multicolumn{2}{|c|}{ Mean number of MetS criteria } & $3.6 \pm 0.7$ & $1.4 \pm 0.5$ & 0.001 \\
\hline \multicolumn{2}{|c|}{$\mathrm{FT}_{4}(\mathrm{ng} / \mathrm{dl})$} & $1.2 \pm 0.2$ & $1.2 \pm 0.2$ & 0.194 \\
\hline \multicolumn{2}{|l|}{ TSH $(\mu \mathrm{IU} / \mathrm{ml})$} & $2.5 \pm 2.4$ & $1.9 \pm 1.7$ & 0.010 \\
\hline
\end{tabular}

a) MetS: metabolic syndrome, b) $\mathrm{FT}_{4}$ : free thyroxine c) $\mathrm{TSH}$ : thyroid-stimulating hormone d) data are expressed as mean \pm SD unless otherwise is indicated.

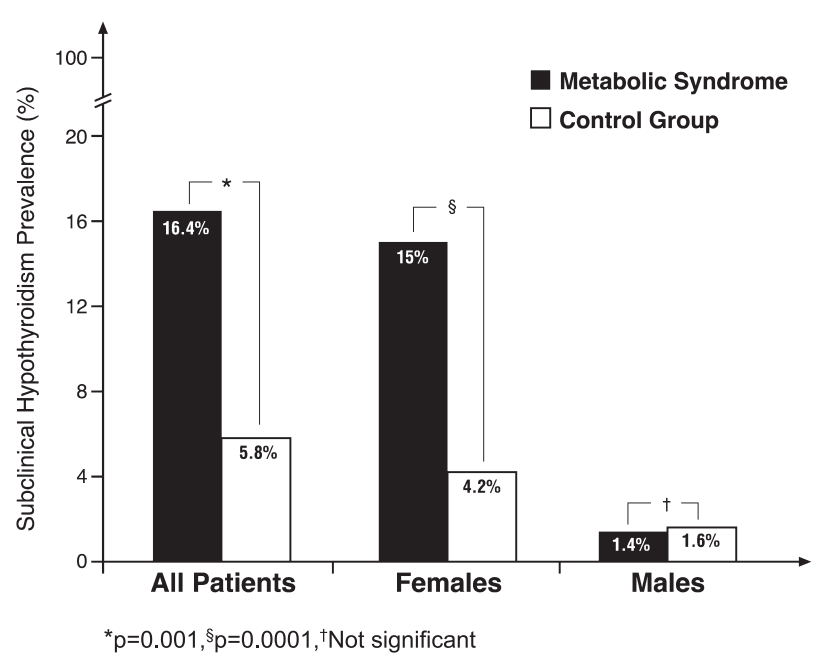

Fig. 1. Comparison of groups according to prevalence of subclinical hipothyroidism

population and our findings suggest that $\mathrm{SCH}$ should be investigated in at least particular group of MetS patients.

MetS is a cluster of cardiometabolic risk factors and it is characterized by inflammation [1]. It is known that cardiovascular system is very sensitive to thyroid function. Both hyperthyroidism and hypothyroidism are mostly presented by cardiovascular manifestations [12, 13]. On the other hand, a lesser degree of thyroid hormone deficiency may also affect the cardiovascular system. $\mathrm{SCH}$ has been found to be associated with atherosclerotic cardiovascular disease, and multiple mechanisms such as altered coagulation parameters, hyperhomocysteinemia, and low-grade chronic inflammation may accompany this process [14-17]. It has been shown that $\mathrm{C}$-reactive protein (CRP) value is elevated in progressive thyroid failure and metabolic syndrome [18, 19]. Tuzcu et al. [17] reported that high-sensitive C-reactive protein (hs-CRP) levels were higher in patients with $\mathrm{SCH}$ compared to controls. In that study, they also found a positive correlation between hs-CRP and insulin levels in both male and female $\mathrm{SCH}$ patients.

$\mathrm{SCH}$ is a frequent condition in the general population. According to National Health and Nutrition Examination Survey (NHANES III) data, SCH prevalence is $4.3 \%$ among United States population [20]. On the other hand, some series reported even higher $\mathrm{SCH}$ prevalence. Kvetny et al. [21] found a $\mathrm{SCH}$ prevalence of $19.7 \%$ among 1212 male and female cases aged between 20-69 y and without any known thyroid disease. The Rotterdam Study found $10.8 \%$ prevalence among elderly women and The Frementle Diabetes Study found a $8.6 \%$ prevalence among women with type 2 diabetes [22,23]. In our study, we found $5.8 \%$ prevalence in the control group, in contrast we obtained a higher value for MetS patients (16.4\%).

Hypothyroidism is a clinical condition leading to hy- 
Table 2. Bivariate analysis for subclinical hypothyroidism in patients with metabolic syndrome

\begin{tabular}{|c|c|c|c|c|}
\hline & & $\mathrm{SCH}(+)$ & $\mathrm{SCH}(-)$ & \multirow{2}{*}{$p$} \\
\hline & & $\mathrm{n}, \%$ & $\mathrm{n}, \%$ & \\
\hline \multirow[t]{2}{*}{ Gender } & female & $33(19.8)$ & $134(80.2)$ & \multirow[t]{2}{*}{0.016} \\
\hline & male & $3(5.7)$ & $50(94.3)$ & \\
\hline \multirow[t]{2}{*}{ Age (year) } & $<50$ & $16(14.4)$ & $95(85.6)$ & \multirow[t]{2}{*}{0.430} \\
\hline & $\geq 50$ & $20(18.3)$ & $89(81.7)$ & \\
\hline \multirow[t]{2}{*}{ Body mass index $\left(\mathrm{kg} / \mathrm{m}^{2}\right)$} & $\geq 30$ & $24(18.6)$ & $105(81.4)$ & \multirow[t]{2}{*}{0.132} \\
\hline & $<30$ & $6(10)$ & $54(90)$ & \\
\hline \multirow[t]{4}{*}{ Waist circumference $(\mathrm{cm})$} & female $>88$ & $30(19.6)$ & $123(80.4)$ & \multirow[t]{2}{*}{0.870} \\
\hline & female $\leq 88$ & $3(21.4)$ & $11(78.6)$ & \\
\hline & male $>102$ & $1(3.1)$ & $31(96.9)$ & \multirow[t]{2}{*}{0.555} \\
\hline & male $\leq 102$ & $2(9.5)$ & $19(90.5)$ & \\
\hline \multirow{2}{*}{$\begin{array}{l}\text { Blood pressure }(\mathrm{mmHg}) \\
\quad \text { (systolic, diastolic) }\end{array}$} & $\geq 130, \geq 85$ & $33(18)$ & $150(82)$ & \multirow[t]{2}{*}{0.137} \\
\hline & $<130,<85$ & $3(8.1)$ & 34 (91.9) & \\
\hline \multirow[t]{2}{*}{ Triglycerides (mg/dl) } & $\geq 150$ & $23(15.9)$ & $122(84.1)$ & \multirow[t]{2}{*}{0.780} \\
\hline & $<150$ & $13(17.3)$ & $62(82.7)$ & \\
\hline \multirow[t]{2}{*}{ HDL cholesterol (mg/dl) } & female $\geq 50$, male $\geq 40$ & $25(18.9)$ & $107(81.1)$ & \multirow[t]{2}{*}{0.206} \\
\hline & female $<50$, male $<40$ & $11(12.5)$ & $77(87.5)$ & \\
\hline \multirow[t]{2}{*}{ Fasting blood glucose (mg/dl) } & $\geq 110$ & $16(14.2)$ & $97(85.8)$ & \multirow[t]{2}{*}{0.364} \\
\hline & $<110$ & $20(18.7)$ & $87(81.3)$ & \\
\hline \multicolumn{2}{|c|}{$\mathrm{FT}_{4}(\mathrm{ng} / \mathrm{dl}$, mean $\pm \mathrm{SD})$} & $1.1 \pm 0.2$ & $1.2 \pm 0.2$ & 0.001 \\
\hline \multicolumn{2}{|c|}{$\mathrm{TSH}(\mu \mathrm{IU} / \mathrm{ml}$, mean $\pm \mathrm{SD})$} & $7.2 \pm 2.5$ & $1.6 \pm 0.9$ & 0.001 \\
\hline
\end{tabular}

a) $\mathrm{SCH}$ : subclinical hypothyroidism b) $\mathrm{FT}_{4}$ : free thyroxine c) $\mathrm{TSH}$ : thyroid-stimulating hormone

pertension, dyslipidemia and disorders of carbohydrate metabolism. Both overt and subclinical hypothyroidism unfavorably effect biochemical parameters [2426]. On the other hand, it has been reported that these abnormalities can be reversed by levothyroxine replacement therapy [27, 28].

Environmental and genetic factors are known to have an effect on MetS [3]. Diagnosis and management of MetS necessitates the prior identification of any other condition resulting in that particular clinical presentation and its treatment. Following questions were explored in the present study: is the presence of MetS a prompting situation to investigate $\mathrm{SCH}$ among patients without clinical evidence of a thyroid function disorder, and is SCH frequently observed at least in a particular group of MetS patients, a syndrome quite common among normal population. SCH was found one in every six patients with MetS, supporting our hypothesis. If long term results of thyroid replacement treatment could be demonstrated, an improvement of MetS may also be seen.

$\mathrm{SCH}$ is known to be more common among female gender [29], so in the present study a higher prevalence is also expected among female patients. In addition, the increased risk found by multivariate analyses for female gender supports this relation. An association between MetS and SCH prevalence could only be demonstrated for female patients, on the other hand, number of male patients with $\mathrm{SCH}$ was quite low in both groups (3 male patients in MetS group and controls), which may serve as a potential cause a bias in statistical analysis.

In addition to its main increasing effect on total and LDL cholesterol, $\mathrm{SCH}$ is also known to increase blood pressure and triglyceride levels and to decrease HDL cholesterol levels [30]. As expected, the present study found higher blood pressure, total and LDL cholesterol and triglyceride levels and lower HDL cholesterol levels among MetS patients compared to controls. However, multivariate analysis did not demonstrate an association between these parameters and $\mathrm{SCH}$.

In conclusion, investigation for $\mathrm{SCH}$ prior to the initiation of treatment may be a reasonable strategy for MetS patients. 
Table 3. Multivariate analysis for subclinical hypothyroidism in patients with metabolic syndrome

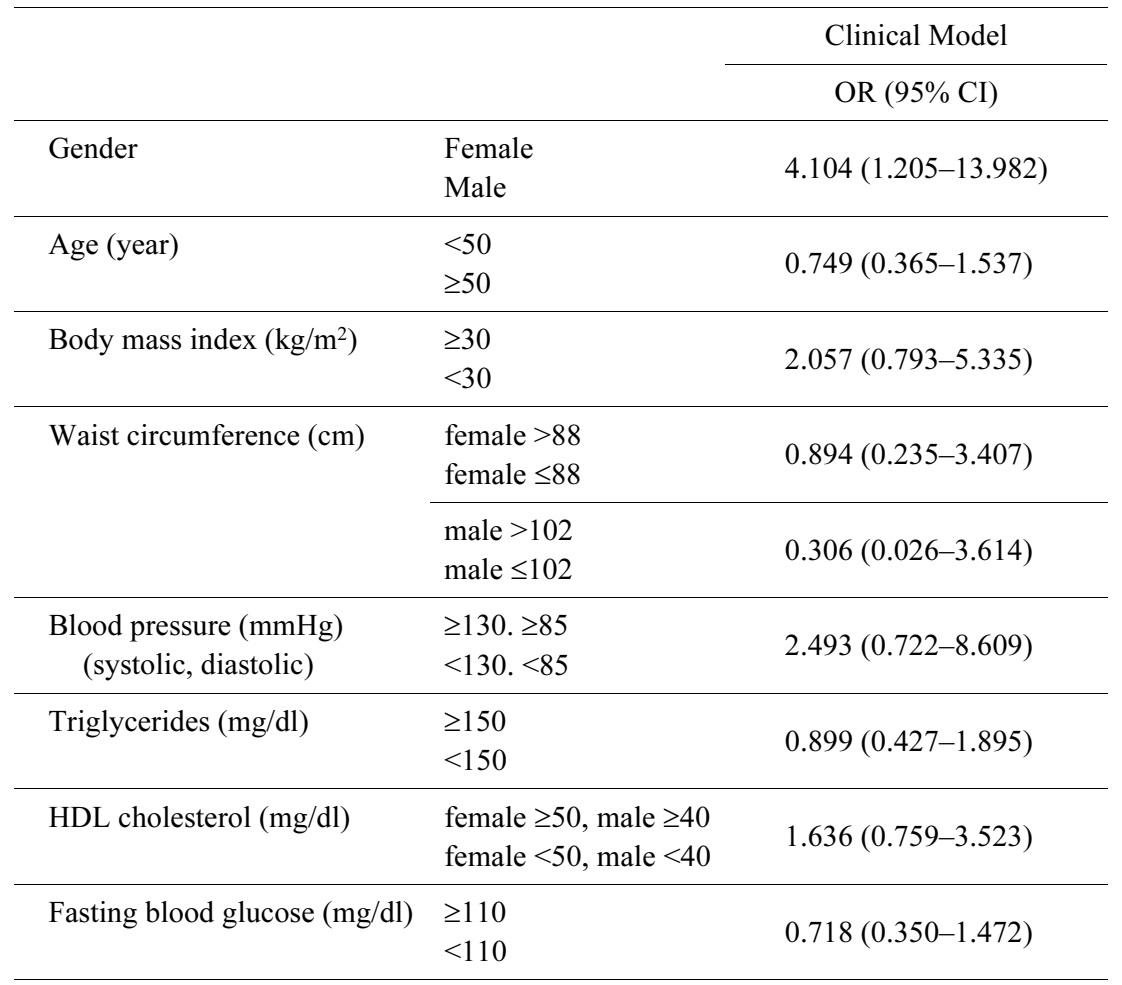

a) OR; odds ratio

\section{References}

1. Grundy SM (2006) Metabolic syndrome: connecting and reconciling cardiovascular and diabetes worlds. $J$ Am Coll Cardiol 47: 1093-1100.

2. Tkac I (2005) Metabolic syndrome in relationship to type 2 diabetes and atherosclerosis. Diabetes Res Clin Pract 68 (Suppl): S2-9.

3. Grundy SM, Cleeman JI, Daniels SR, Donato KA, Eckel RH, Franklin BA, Gordon DJ, Krauss RM, Savage PJ, Smith SC Jr, Spertus JA, Costa F; American Heart Association; National Heart, Lung, and Blood Institute (2005) Diagnosis and management of the metabolic syndrome: an American Heart Association/ National Heart, Lung, and Blood Institute Scientific Statement. Circulation 112: 2735-2752.

4. Ford ES, Giles WH, Dietz WH (2002) Prevalence of the metabolic syndrome among US adults. JAMA 287: 356-359.

5. Gharib H, Tuttle RM, Baskin HJ, Fish LH, Singer PA, McDermott MT (2005) Subclinical thyroid dysfunction: a joint statement on management from the American Association of Clinical Endocrinologists, the American Thyroid Association, and the Endocrine Society. J Clin Endocrinol Metab 90: 581-585.
6. Monzani F, Dardano A, Caraccio N (2006) Does treating subclinical hypothyroidism improve markers of cardiovascular risk? Treat Endocrinol 5: 65-81.

7. Foldes J, Banos C, Winkler G (2004) Subclinical hypothyroidism and arteriosclerosis. Orv Hetil 145: 1601-1607.

8. Walsh JP, Bremner AP, Bulsara MK, O'Leary P, Leedman PJ, Feddema P, Michelangeli V (2005) Subclinical thyroid dysfunction as a risk factor for cardiovascular disease. Arch Intern Med 165: 2451-2452.

9. Executive Summary of the Third Report of the National Cholesterol Education Program (NCEP) (2001) Expert panel on detection, evaluation and treatment of high blood cholesterol in adults. (Adult Treatment Panel III ). JAMA 285: 2486-2497.

10. Maggio CA, Pi-Sunyer FX (1997) The prevention and treatment of obesity: application to type 2 diabetes. Diabetes Care 20: 1744-1766.

11. Friedewald WT, Levy RI, Fredrickson DS (1972) Estimation of the concentration of low-density lipoprotein in plasma, without use of the preparative ultracentrifuge. Clin Chem 18: 499-502.

12. Tamer I, Sargin M, Sargin H, Seker M, Babalik E, 
Tekce M, Yayla A (2005) The evaluation of left ventricular hypertrophy in hypertensive patients with subclinical hyperthyroidism. Endocr J 52: 421-425.

13. Hamano K, Inoue M (2005) Increased risk for atherosclerosis estimated by pulse wave velocity in hypothyroidism and its reversal with appropriate thyroxine treatment. Endocr J 52: 95-101.

14. Biondi B, Klein I (2004) Hypothyroidism as a risk factor for cardiovascular disease. Endocrine 24: 1-13.

15. Guldiken S, Demir M, Turgut B, Altun BU, Arikan E, Kara M (2005) Global fibrinolytic capacity in patients with subclinical hypothyroidism. Endocr $J$ 52: 363367.

16. Ozmen B, Ozmen D, Parildar Z, Mutaf I, Turgan N, Bayindir O (2006) Impact of renal function or folate status on altered plasma homocysteine levels in hypothyroidism. Endocr J 53: 119-124.

17. Tuzcu A, Bahceci M, Gokalp D, Tuzun Y, Gunes K (2005) Subclinical hypothyroidism may be associated with elevated high-sensitive C-reactive protein (low grade inflammation) and fasting hyperinsulinemia. Endocr J 52: 89-94.

18. Christ-Crain M, Meier C, Guglielmetti M, Huber PR, Riesen W, Staub JJ, Muller B (2003) Elevated C-reactive protein and homocysteine values: cardiovascular risk factors in hypothyroidism? A cross-sectional and a double-blind, placebo controlled trial. Atherosclerosis 166: 379-386.

19. Ridker PM, Wilson PW, Grundy SM (2004) Should Crective protein be added to metabolic syndrome and to assessment of global cardiovascular risk? Circulation 109: 2818-2825.

20. Hollowell JG, Staehling NW, Flanders WD, Hannon WH, Gunter EW, Spencer CA, Braverman LE (2002) Serum TSH, T(4), and thyroid antibodies in the United States population (1988 to 1994): National Health and Nutrition Examination Survey (NHANES). J Clin Endocrinol Metab 87: 486-488.
21. Kvetny J, Heldgaard PE, Bladbjerg EM, Gram J (2004) Subclinical hypothyroidism is associated with a lowgrade inflammation, increased triglyceride levels and predicts cardiovascular disease in males below 50 years. Clin Endocrinol (Oxf) 61: 232-238.

22. Hak AE, Pols HA, Visser TJ, Drexhage HA, Hofman A, Witteman JC (2000) Subclinical hypothyroidism is an independent risk factor for atherosclerosis and myocardial infarction in elderly women: the Rotterdam Study. Ann Intern Med 132: 270-278.

23. Chubb SA, Davis WA, Inman Z, Davis TM (2005) Prevalence and progression of subclinical hypothyroidism in women with type 2 diabetes: the Fremantle Diabetes Study. Clin Endocrinol (Oxf) 62: 480-486.

24. Duntas LH (2002) Thyroid disease and lipids. Thyroid 12: 287-293.

25. Smithson MJ (1998) Screening for thyroid dysfunction in a community population of diabetic patients. Diabet Med 15: 148-150.

26. Pearce EN (2004) Hypothyroidism and dyslipidemia: modern concepts and approaches. Curr Cardiol Rep 6: 451-456.

27. Fadeyev VV, Sytch J, Kalashnikov V, Rojtman A, Syrkin A, Melnichenko G (2006) Levothyroxine replacement therapy in patients with subclinical hypothyroidism and coronary artery disease. Endocr Pract 12: 5-17.

28. Serter R, Demirbas B, Korukluoglu B, Culha C, Cakal E, Aral Y (2004) The effect of L-thyroxine replacement therapy on lipid based cardiovascular risk in subclinical hypothyroidism. Invest J Endocrinol 27: 897903.

29. Helfand M, Redfern CC (1998) Screening for thyroid disease: An update. Ann Intern Med 129: 144-158.

30. McDermott MT, Ridgway EC (2001) Subclinical hypothyroidism is mild thyroid failure and should be treated. J Clin Endocrinol Metab 86: 4585-4590. 